\title{
Failure Characteristics and Confined Permeability of an Inclined Coal Seam Floor in Fluid-Solid Coupling
}

\author{
Jian Sun $\mathbb{D}^{1,2}$ Lianguo Wang $\mathbb{D}^{2}$, and Guangming Zhao ${ }^{1}$ \\ ${ }^{1}$ School of Energy and Safety, Anhui University of Science and Technology, Huainan 232001, China \\ ${ }^{2}$ State Key Laboratory of Coal Resources and Safe Mining, China University of Mining and Technology, Xuzhou 221116, China \\ Correspondence should be addressed to Jian Sun; sj323@cumt.edu.cn
}

Received 4 May 2018; Accepted 10 July 2018; Published 1 August 2018

Academic Editor: Hugo C. Biscaia

Copyright ( $\odot 2018$ Jian Sun et al. This is an open access article distributed under the Creative Commons Attribution License, which permits unrestricted use, distribution, and reproduction in any medium, provided the original work is properly cited.

Secondary development of FLAC ${ }^{3 \mathrm{D}}$ software was carried out based on FISH language, and a 3D fluid-solid coupling numerical calculation model was established for an inclined seam mining above a confined aquifer in Taoyuan Coal Mine. A simulation study was implemented on the mining failure depth of an inclined coal seam floor, conducting height of confined water, and the position of workface floor with easy water inrush during advancement of workface. Results indicated that, during the advancement of the inclined coal seam's workface, obvious equivalent stress concentration areas existed in the floor strata, and the largest equivalent stress concentration area was located at the low region of workface floor. When the inclined coal seam workface advanced to about $80 \mathrm{~m}$, the depth of floor plastic failure zone reached the maximum at approximately $15.0 \mathrm{~m}$, and the maximum failure depth was located at the low region of the workface floor. Before the inclined workface mining, original confined water conducting existed on the top interface of the confined aquifer. The conducting height of the confined water reached the maximum at about $11.0 \mathrm{~m}$ when the workface was pushed forward from an open-off cut at about $80 \mathrm{~m}$. Owing to the barrier effect of the "soft-hard-soft" compound water-resistant strata of the workface floor, pore water pressure and its seepage velocity in the floor strata were unchanged after the workface advanced to about $80 \mathrm{~m}$. After the strata parameters at the workface floor were changed, pore water pressure of the confined water could pass through the lower region of the inclined workface floor strata and break through the barrier of the "softhard-soft" compound water-resistant strata of the workface floor and into the mining workface, resulting in the inclined coal seam floor water inrush. Results of this study can provide a basis for predicting, preventing, and governing the inclined coal seam floor water inrush above confined aquifer.

\section{Introduction}

Floor water inrush severely threatens the safety production of coal mines. It is a phenomenon in which confined water floods into an excavation space after deformation and failure of the floor strata under the joint effects of mininginduced stress and confined water pressure [1-3]. With the increased coal mining depth and magnified mining intensity, the workface floor is increasingly and seriously threatened by Ordovician karst water, highlighting problems related to the prediction, prevention, and treatment of water inrush $[4,5]$. Before coal seam mining, floor confined water along upside preexisting fractures of mudstone or sandstone intrude to a certain height to form an original conducting zone of floor confined water. After coal seam mining, the stress field and seepage field of floor strata change and form a floor mining failure zone. The intruding height of confined water presents upward conducting to form a progressive conducting zone of floor confined water. Water inrush from the seam floor may occur when the progressive conducting zone connects with the floor mining failure zone [6]. Therefore, water inrush from the seam floor is the product of the joint coupling effect of mining-induced stress and confined water pressure. The mechanism of water inrush from the seam floor can be revealed well only from the angle of fluid-solid coupling to predict water inrush from coal seam floor.

Numerous scholars have conducted relevant studies on water inrush from the coal seam floor based on the fluidsolid coupling mechanism. Fenghua and Yuanjiang [7] used 
the fluid-solid coupling module in FLAC ${ }^{3 \mathrm{D}}$ numerical simulation software to simulate floor plastic zone and floor stress change during coal seam mining as well as water flow vector distribution during dynamic mining. Duoxi and Haifeng [8] conducted a numerical simulation study on the mining-seepage-strain mechanism of workface floor rock mass using the $3 \mathrm{D}$ rapid Lagrange fluid-solid coupling analysis module by changing the permeability coefficients. Wei and Dejin [9] implemented the finite element strength reduction method in FLAC $^{3 \mathrm{D}}$ and applied it to the simulation of water inrush from a coal seam floor. Wenmin et al. [10] used the powerful fluid-solid coupling function of FLAC $^{3 \mathrm{D}}$ to establish the numerical analysis model of the workface above a confined aquifer and conduct a simulation analysis of strata displacement, stress distribution laws, and confined water-conducting height in a floor water-resisting layer.

However, the abovementioned fluid-solid coupling is only realized by assigning a fixed permeability coefficient to each stratum in the model. The permeability of surrounding rock during the coal seam mining process is not changed, and only the pore water pressure varies with mining-induced stress. During actual coal seam mining, the permeability of surrounding rock in the stope continuously changes and the changed fluid seepage force would result in a change of the effective mining stress. The seepage force and effective mining stress would interact with each other to realize the fluid-solid coupling effect. Therefore, Xiaorong et al. [11] conducted a simulation study on floor mining stress and surrounding rock permeability in three combined characteristics of floor strata under a fluid-solid coupling condition. Yanlin et al. [12] established an analysis method combining fluid-solid coupling and strength reduction of water inrush from the front roadway on the basis of fluidsolid coupling theory of water inrush from a confined karst cave and the strength reduction idea of an inrush-preventive rock column. They then discussed the fluid-solid coupling effect and safety stock of the inrush-preventive rock columns.

China has various coal seam occurrence conditions and a complicated hydrogeology with considerable changes in coal seam dip angle. It has inclined coal seams with large dip angles as well as nearly flat seams with small dip angles [13-16]. Water pressure borne by floor strata from an underlying confined aquifer is no longer uniformly distributed water pressure but has a certain water pressure gradient along the dip direction for an inclined coal seam. In the meantime, owing to the asymmetric characteristics of loadbearing state of the inclined stope surrounding rocks, the failure characteristics of the inclined workface floor strata are different from those of the nearly flat seams with small dip angles [13]. However, the above study results are mostly based on the engineering background for flat and nearly flat seams [7-12]. Research on relevant problems such as fluidsolid coupling failure characteristics and confined permeability characteristics of an inclined coal seam floor above a confined aquifer should be carried out further.

In the current study, the inclined coal seam mining above a confined aquifer in China Taoyuan Coal Mine was taken as the engineering background, and the secondary development of FLAC ${ }^{3 \mathrm{D}}$ software was implemented based on FISH language. A 3D fluid-solid coupling numerical model for an inclined coal seam mining above a confined aquifer was established. The synchronous influence of floor seepage force and mining stress was realized during the mining process of the inclined coal seam. Mining failure depth, confined water-conducting height, and position of workface floor with easy water inrush were studied and analyzed. The zones with water inrush risks were divided at the workface floor to provide a basis for predicting, preventing, and governing the water inrush from the inclined coal seam floor above a confined aquifer.

\section{Fluid-Solid Coupling Model of an Inclined Coal Seam Floor}

2.1. Engineering Background. Strike length and inclined length of the 1066 inclined coal seam workface in Taoyuan Coal Mine of Huaibei Mining Group Co. Ltd. in China are 790 and $112 \mathrm{~m}$, respectively. Burial depth of coal seam at the track trough is $500 \mathrm{~m}$, average thickness of the coal seam is $3.4 \mathrm{~m}$, and dip angle is $28^{\circ}$. The roof strata of the coal seam are mainly fine sandstone, siltstone, and medium sandstone. Taiyuan Formation limestone aquifer is approximately $53 \mathrm{~m}$ away below the 1066 inclined coal seam workface floor. Its water pressure reaches as high as 3.0 $\mathrm{MPa}$, and floor water inrush danger exists during the mining process of the 1066 workface. Therefore, the mining failure depth of the 1066 inclined coal seam workface floor, confined water-conducting height, and position of the workface floor with easy water inrush, and partition regions with water inrush dangers from inclined coal seam floor must be determined through a numerical simulation method. Consequently, water inrush from the 1066 inclined coal seam floor can be predicted, prevented, and treated.

2.2. Fluid-Solid Coupling Equation. In current studies on deformation failure and water inrush mechanism from the coal seam floor above a confined aquifer, the influence of seepage field caused by the floor confined water load on stress field of the floor strata is generally neglected. Floor confined water load is expressed in the forms of hydrostatic pressure and pumping pressure. A specific water pressure load distribution form corresponds to a specific seepage field distribution form in any permeable medium. The change of seepage field distribution would also cause a change of water pressure load. Therefore, the influence of seepage field on stress field is realized by changing the volumetric strain of the coal seam floor strata. On the other hand, the change of pore pressure of coal seam floor strata would cause a change of effective stress, which would significantly change the fracture opening, flow velocity, and distribution form of fluid pressure in the fracture. Stress field of the strata affects the permeability coefficient of strata fracture by influencing strata volumetric strain to 
finally affect seepage field in the strata fracture. In the meantime, the seepage field affects stress field distribution form by influencing the strata volumetric strain. This effect is called the interaction mechanism between stress field and seepage field in the strata.

An equivalent continuous medium model is adopted during simulation of the strata fluid-solid coupling using FLAC $^{3 \mathrm{D}}$ software. Strata are regarded as porous media; fluid flow in strata porous media is in accordance with Darcy laws and meets the Biot fluid-solid coupling equation [8], as follows:

$$
\begin{array}{r}
G \nabla^{2} u_{j}-(G+\lambda) \frac{\partial \varepsilon_{\mathrm{v}}}{\partial x_{j}}-\frac{\partial p}{\partial x_{j}}+f_{x j}=0 \\
K \nabla^{2} p-\frac{1}{S} \frac{\partial p}{\partial t}+\frac{\partial \varepsilon_{\mathrm{v}}}{\partial t}=0
\end{array}
$$

where $G$ and $\lambda$ are the Lame constants; $\varepsilon_{\mathrm{v}}$ is the volumetric strain; $p$ is the pore water pressure; $x_{j}, u_{j}$, and $f_{x j}$ are the coordinate, displacement, and volume forces in $j$ direction, respectively; $K$ is the permeability coefficient; and $S$ is the storage coefficient. The term of $\partial p / \partial x_{j}$ reflects the influence of seepage field on the solid frame, and its essence is that pore pressure generated during fluid flow affects the effective stress and deformation of the solid frame. The term of $\partial \varepsilon_{\mathrm{v}} / \partial t$ reflects the influence of volumetric deformation of solid frame on the seepage field. The above equation can reflect the interaction between pore pressure dissipation and solid frame deformation.

The main reason for coal seam floor water inrush is the influence of mining on the floor strata, which in turn causes the destroyed fracture in and enhances the permeability of the floor strata. Existing studies indicate that the permeability of strata under stress is not a constant, but instead continuously changes with the development of fracture during the rock mass stress-strain process. However, the medium permeability in (1) is a constant quantity, which does not vary with the medium stress field. If the permeability coefficient of the rock mass is still considered a fixed value during numerical simulation of fluid-solid coupling using FLAC, this finding does not accord with the engineering reality.

To reflect the change of medium permeability with the medium stress field, the relationship between permeability coefficient and strain as proposed by Elsworth and Mao [17] is selected in this paper as the control equation of permeability coefficient during the numerical simulation of fluid-solid coupling in rock mass media:

$$
K=k_{0} \times\left(\frac{1+\Delta \varepsilon}{n}\right)^{2}
$$

where $k_{0}$ is the initial permeability coefficient of rock mass media, $\Delta \varepsilon$ is the increment of volumetric strain of rock mass media, and $n$ is the porosity of rock mass media.

Equation (3) is obtained by substituting (2) into (1):

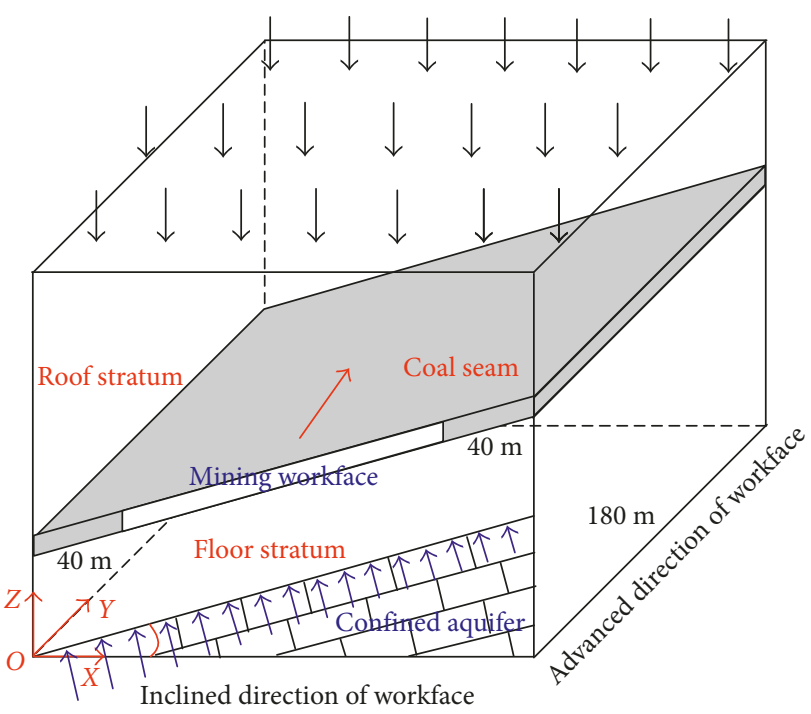

FIGURE 1: 3D fluid-solid coupling numerical calculation model for an inclined coal seam with strike longwall mining.

$$
\begin{aligned}
G \nabla^{2} u_{j}-(G+\lambda) \frac{\partial \varepsilon_{\mathrm{v}}}{\partial x_{j}}-\frac{\partial p}{\partial x_{j}}+f_{x j} & =0, \\
k_{0}\left(\frac{1+\Delta \varepsilon}{n}\right)^{2} \nabla^{2} p-\frac{1}{S} \frac{\partial p}{\partial t}+\frac{\partial \varepsilon_{\mathrm{v}}}{\partial t} & =0 .
\end{aligned}
$$

After (3) is embedded into FLAC ${ }^{3 \mathrm{D}}$ software through programming procedures using FISH language, a synchronous change of floor strata permeability with rock mass deformation during coal seam mining can be realized to achieve the fluid-solid coupling simulation of water inrush from coal seam floor.

2.3. Fluid-Solid Coupling Model. According to the strike longwall mining characteristic of the 1066 inclined coal seam workface in Taoyuan Coal Mine, the secondary development of FLAC ${ }^{3 \mathrm{D}}$ software was implemented using FISH language, and a 3D fluid-solid coupling numerical calculation model for an inclined coal seam was established with strike longwall mining, as shown in Figure 1. In the model, $x$ is the inclined direction of the workface, $y$ is the advanced direction of the workface, and the advanced direction is shown by a red arrow. The horizontal width of coal columns at two sides of the workface is $40 \mathrm{~m}$, and the strike length of the workface ( $y$ direction) is $180 \mathrm{~m}$. The mode is excavated step by step, from $y=40 \mathrm{~m}$ to $y=140 \mathrm{~m}$. Each step is $20 \mathrm{~m}$, the full height is excavated, and the total number of excavated steps is 5 . Water pressure acting on the inclined coal seam floor strata presents linear growth along the inclined direction of the coal seam. The water pressure of the floor confined aquifer at the upper side of the workface is $3.0 \mathrm{MPa}$, and that at the lower side of the workface is $3.82 \mathrm{MPa}$. The model undersurface confined displacement in the vertical direction, while the front, back, left, and right surfaces confined displacement in the horizontal direction. The upper surface in the model is free surface, and the overlying strata load, 
TABle 1: Physical and mechanical parameters of the roof and floor strata of the 1066 inclined coal seam workface.

\begin{tabular}{|c|c|c|c|c|c|c|c|c|c|c|}
\hline Number & Lithology & $\begin{array}{l}\text { Thickness } \\
\text { (m) }\end{array}$ & $\begin{array}{c}\text { Density } \\
\left(\mathrm{kg} \cdot \mathrm{m}^{-3}\right)\end{array}$ & $\begin{array}{c}\text { Bulk } \\
\text { modulus } \\
(\mathrm{GPa})\end{array}$ & $\begin{array}{c}\text { Shear } \\
\text { modulus } \\
(\mathrm{GPa})\end{array}$ & $\begin{array}{c}\text { Tensile } \\
\text { strength } \\
(\mathrm{MPa})\end{array}$ & $\begin{array}{c}\text { Cohesion } \\
(\mathrm{MPa})\end{array}$ & $\begin{array}{l}\text { Internal } \\
\text { friction } \\
\text { angle }\left(^{\circ}\right)\end{array}$ & $\begin{array}{c}\text { Permeability } \\
\text { coefficient } \\
\left(\mathrm{m} \cdot \mathrm{s}^{-1}\right)\end{array}$ & Porosity \\
\hline 1 & $\begin{array}{l}\text { Medium } \\
\text { sandstone }\end{array}$ & 14.0 & 2650 & 2.78 & 2.63 & 0.95 & 3.90 & 41 & $0.8 e-12$ & 0.12 \\
\hline 2 & Mudstone & 9.5 & 2620 & 1.86 & 0.53 & 0.50 & 2.70 & 30 & $0.8 e-13$ & 0.08 \\
\hline 3 & $\begin{array}{l}\text { Medium } \\
\text { sandstone }\end{array}$ & 4.0 & 2650 & 2.78 & 2.63 & 0.95 & 3.90 & 41 & $0.8 e-12$ & 0.12 \\
\hline 4 & Siltstone & 7.5 & 2650 & 4.54 & 4.30 & 1.20 & 4.90 & 40 & $7 e-12$ & 0.14 \\
\hline 5 & $\begin{array}{c}\text { Fine } \\
\text { sandstone }\end{array}$ & 5.0 & 2650 & 3.38 & 3.32 & 1.10 & 5.10 & 42 & $5 e-12$ & 0.14 \\
\hline 6 & 10-coal & 3.4 & 1400 & 1.43 & 1.09 & 0.03 & 1.00 & 25 & $1 e-12$ & 0.15 \\
\hline 7 & Siltstone & 6.0 & 2650 & 4.54 & 4.30 & 1.20 & 4.90 & 40 & $7 e-12$ & 0.13 \\
\hline 8 & $\begin{array}{c}\text { Fine } \\
\text { sandstone }\end{array}$ & 9.0 & 2650 & 3.38 & 3.32 & 1.50 & 3.50 & 38 & $5 e-12$ & 0.13 \\
\hline 9 & $\begin{array}{c}\text { Sand } \\
\text { mudstone }\end{array}$ & 6.5 & 2600 & 1.73 & 1.09 & 0.65 & 2.90 & 25 & $0.6 e-13$ & 0.09 \\
\hline 10 & $\begin{array}{l}\text { Medium } \\
\text { sandstone }\end{array}$ & 12.0 & 2650 & 2.78 & 2.63 & 0.95 & 3.90 & 41 & $0.8 e-12$ & 0.12 \\
\hline 11 & $\begin{array}{c}\text { Sand } \\
\text { mudstone }\end{array}$ & 9.0 & 2600 & 1.73 & 1.09 & 0.65 & 2.90 & 25 & $0.6 e-13$ & 0.09 \\
\hline 12 & $\begin{array}{l}\text { Medium } \\
\text { sandstone }\end{array}$ & 3.0 & 2650 & 2.78 & 2.63 & 0.95 & 3.90 & 41 & $0.8 e-12$ & 0.12 \\
\hline 13 & Siltstone & 5.5 & 2650 & 4.54 & 4.30 & 1.20 & 4.90 & 40 & $0.5 e-12$ & 0.14 \\
\hline 14 & $\begin{array}{l}\text { Medium } \\
\text { sandstone }\end{array}$ & 2.0 & 2650 & 2.78 & 2.63 & 0.95 & 3.90 & 41 & $0.8 e-12$ & 0.12 \\
\hline 15 & Aquifer & 90.0 & 2500 & 4.20 & 3.12 & 1.40 & 3.20 & 38 & $5 e-10$ & 0.31 \\
\hline
\end{tabular}

Note. The unit of permeability coefficient in FLAC ${ }^{3 \mathrm{D}}$ software is different from that in hydraulics, and their conversion relation is $K\left(\mathrm{~m}^{2} / \mathrm{Pa} \cdot \mathrm{s}\right)=K(\mathrm{~cm} / \mathrm{s}) \times$ $1.02 \times 10^{-6}$.

except for the coal seam roof, is loaded to the upper surface of the model in the form of uniformly distributed loads.

With multidrilling geological data and rock mechanics testing of an inclined coal seam floor, the thickness, strength, and location of each of coal seam floor strata, including the water pressure distribution of the confined aquifer, can be determined. Furthermore, the lithology, thickness, density, bulk modulus, shear modulus, tensile strength, cohesion, internal friction angle, permeability coefficient, porosity, and other parameters of each of floor strata of the 1066 inclined coal seam workface can be determined. And Table 1 shows the physical and mechanical parameters of the roof and floor strata of the 1066 inclined coal seam workface in the model (Figure 1).

\section{Fluid-Solid Coupling Failure Characteristics of an Inclined Coal Seam Floor}

3.1. Vertical Stress of Floor along the Inclined Direction of Coal Seam. Figure 2 shows the vertical stress of workface floor along the inclined direction of coal seam with the advancement of workface. The pressure relief range of the floor strata continuously expanded with the advancement of the inclined coal seam workface. Pressure relief range of the workface floor started influencing the floor aquifer when the workface advanced to about $40 \mathrm{~m}$. The effect exerted by pressure relief range of the workface floor on the floor aquifer was enhanced when the workface advanced to about $60 \mathrm{~m}$. When the workface advanced to about $80 \mathrm{~m}$, the influence was enhanced further. With continuous advancement, the influence remained unchanged.

Therefore, pressure relief range of the floor strata was continuously expanded with the advancement of the workface, and it remained unchanged when the workface advanced to about $80 \mathrm{~m}$. This result is due to the stress concentration generated near the open-off cut and in front of the workface in the initial advancement stage of the workface. The stress concentration degrees at the two positions are approximately thrice those of primary rock stress, and they exerted a joint effect on the workface floor strata, resulting in the continuously expanded pressure relief range of the floor strata. Their joint effect tended to be mild on the workface floor strata until the workface advanced to about $80 \mathrm{~m}$, and then the influence on the floor aquifer remained unchanged.

3.2. Equivalent Stress of Floor along the Inclined Direction of Coal Seam. Figure 3 shows the equivalent stress (Mises stress) of workface floor along the inclined direction of coal seam with the advancement of workface. Under the joint effect of mining stress and pore water pressure on workface floor strata, apparent stress concentration zones existed in the floor strata (two sides of workface floor and goaf floor). With the continuous advancement of workface, stress concentration degree and range were 


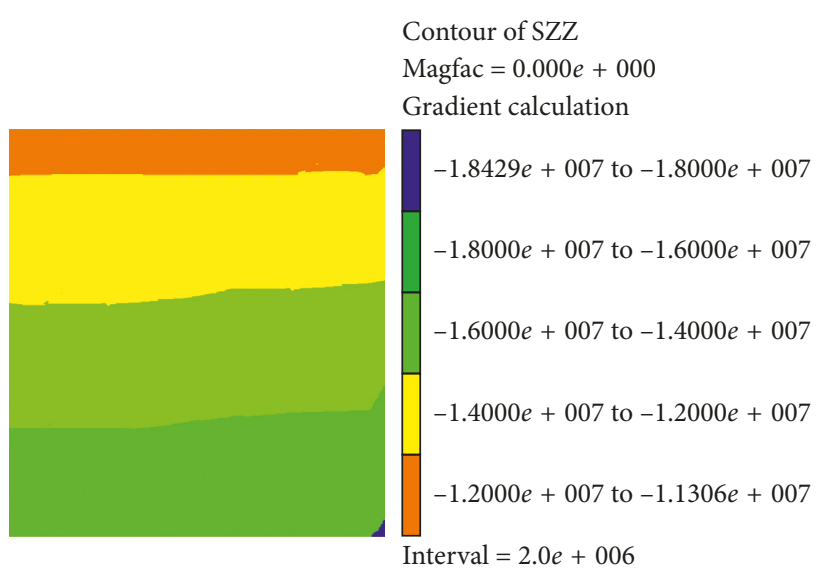

(a)

Contour of SZZ

Magfac $=0.000 e+000$

Gradient calculation

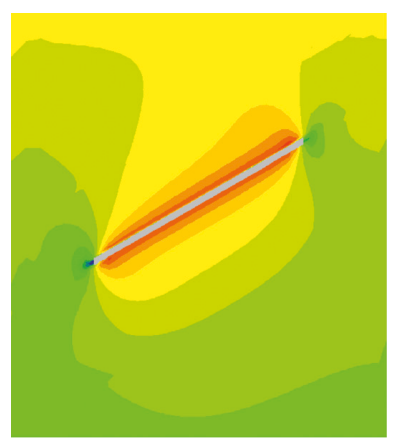

$-2.9906 e+007$ to $-2.8000 e+007$
$-2.8000 e+007$ to $-2.6000 e+007$
$-2.6000 e+007$ to $-2.4000 e+007$
$-2.4000 e+007$ to $-2.2000 e+007$
$-2.2000 e+007$ to $-2.0000 e+007$
$-2.0000 e+007$ to $-1.8000 e+007$
$-1.8000 e+007$ to $-1.6000 e+007$
$-1.6000 e+007$ to $-1.4000 e+007$
$-1.4000 e+007$ to $-1.2000 e+007$
$-1.2000 e+007$ to $-1.0000 e+007$
$-1.0000 e+007$ to $-8.0000 e+006$
$-8.0000 e+006$ to $-6.0000 e+006$
$-6.0000 e+006$ to $-4.0000 e+006$
$-4.0000 e+006$ to $-2.9772 e+006$ Interval $=2.0 e+006$

(c)

\section{Contour of SZZ}

Magfac $=0.000 e+000$

Gradient calculation

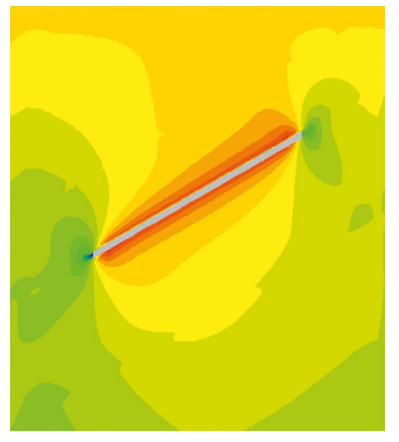

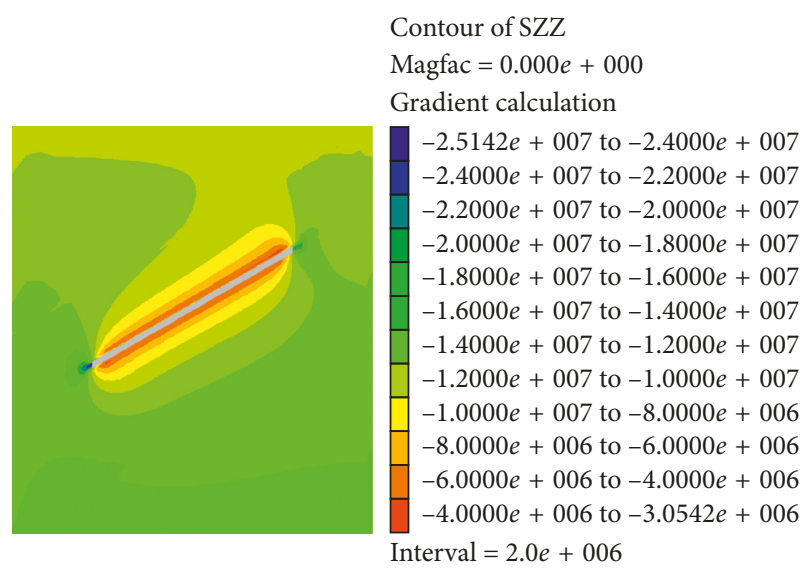

(b)

\section{Contour of SZZ}

Magfac $=0.000 e+000$

Gradient calculation

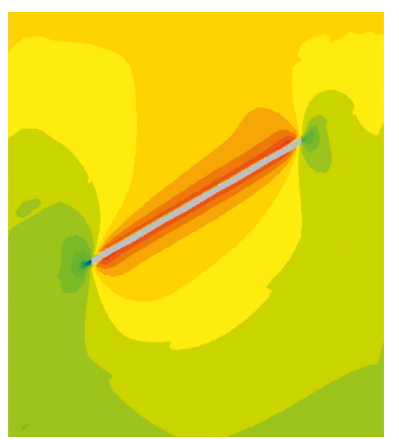

$-3.2742 e+007$ to $-3.2000 e+007$

$-3.0000 e+007$ to $-2.8000 e+007$

$-2.6000 e+007$ to $-2.4000 e+007$

$-2.2000 e+007$ to $-2.0000 e+007$

$-1.8000 e+007$ to $-1.6000 e+007$

$-1.4000 e+007$ to $-1.2000 e+007$

$-1.0000 e+007$ to $-8.0000 e+006$

$-6.0000 e+006$ to $-4.0000 e+006$

$-4.0000 e+006$ to $-2.9266 e+006$

Interval $=2.0 e+006$

(d)

\section{Contour of SZZ}

Magfac $=0.000 e+000$

Gradient calculation

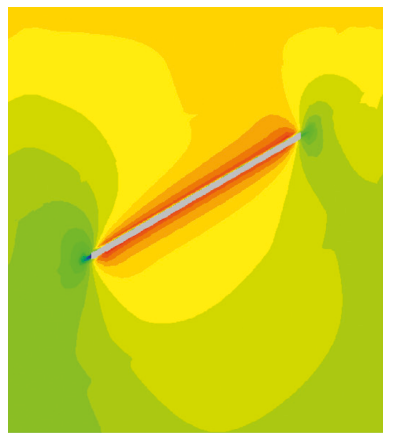

$-3.6769 e+007$ to $-3.6000 e+007$

$-3.4000 e+007$ to $-3.2000 e+007$

$-3.0000 e+007$ to $-2.8000 e+007$

$-2.6000 e+007$ to $-2.4000 e+007$

$-2.2000 e+007$ to $-2.0000 e+007$

$-1.8000 e+007$ to $-1.6000 e+007$

$-1.4000 e+007$ to $-1.2000 e+007$

$-1.0000 e+007$ to $-8.0000 e+006$

$-6.0000 e+006$ to $-4.0000 e+006$

$-4.0000 e+006$ to $-2.4024 e+006$

Interval $=2.0 e+006$

(f)

FigURE 2: Vertical stress of workface floor along the inclined direction of the coal seam with the advancement of the workface. (a) Original vertical stress. (b) Advanced $20 \mathrm{~m}$ of workface. (c) Advanced $40 \mathrm{~m}$ of workface. (d) Advanced $60 \mathrm{~m}$ of workface. (e) Advanced $80 \mathrm{~m}$ of workface. (f) Advanced $100 \mathrm{~m}$ of workface.

continuously expanded. The stress concentration degree and range reached the maximum when the workface advanced to about $80 \mathrm{~m}$. The maximum equivalent stress at the lower side of workface floor was approximately $20.0 \mathrm{MPa}$. The floor stress concentration degree and range remained unchanged with the continuous advancement of workface.
In addition, when the workface advanced to about $80 \mathrm{~m}$, the stress concentration degree and range reached the maximum at the lower side of the workface floor. The stress concentration degree was even greater than that in the goaf floor, and the action range also affected the floor aquifer. Hence, the floor region at the lower side of the workface was 


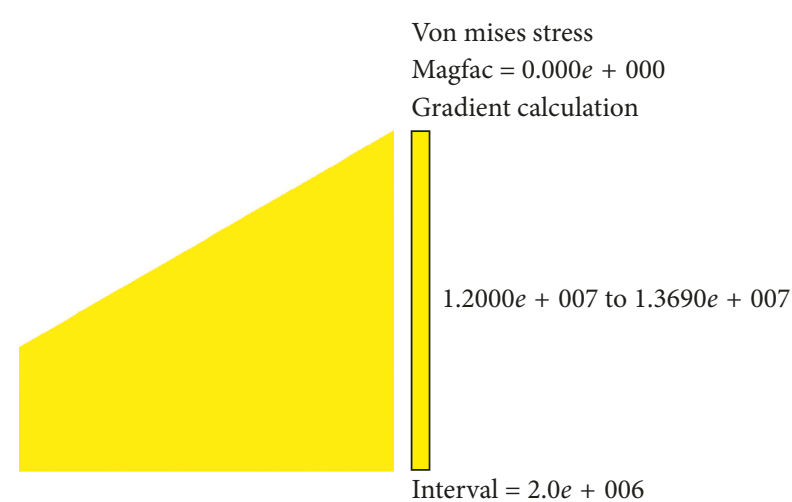

(a)

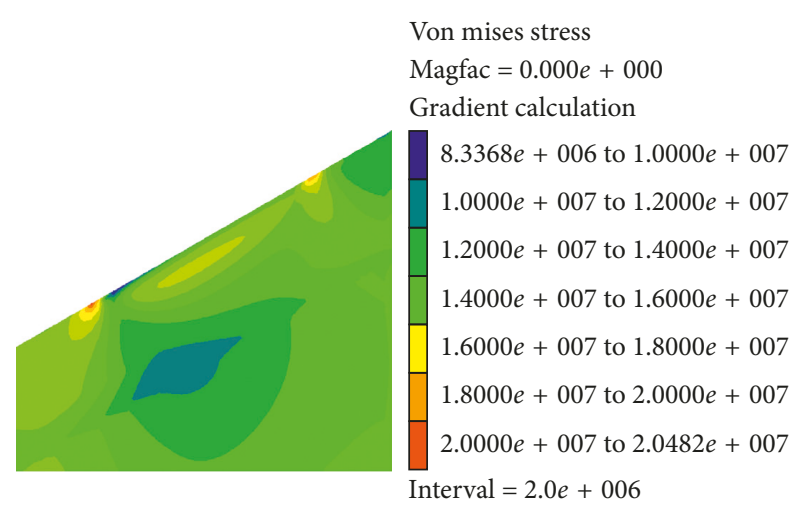

(c)

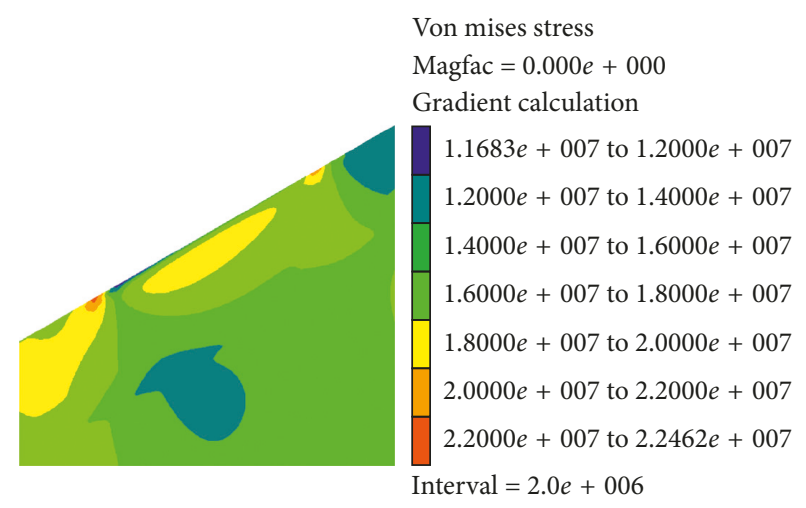

(e)

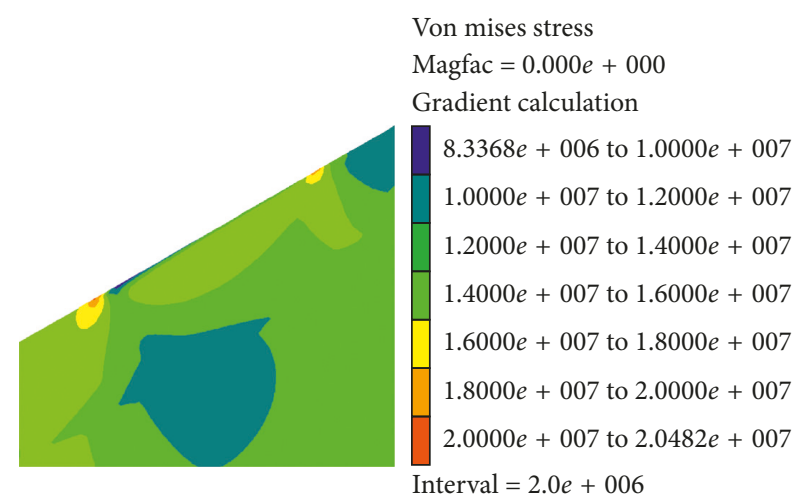

(b)

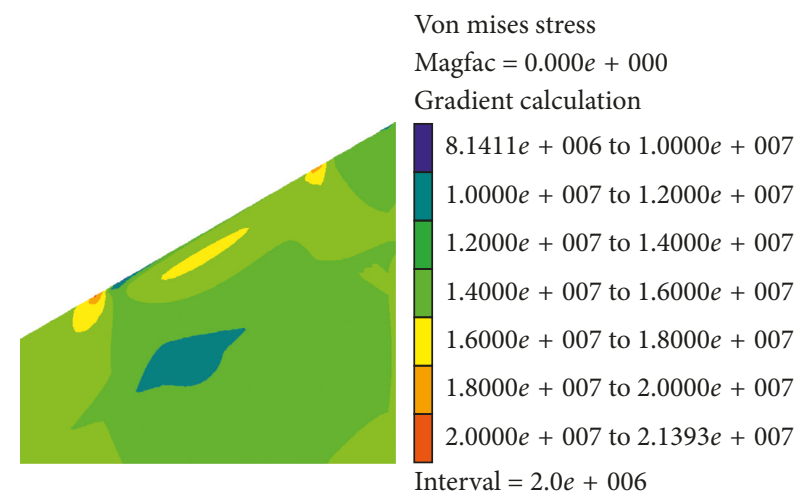

(d)

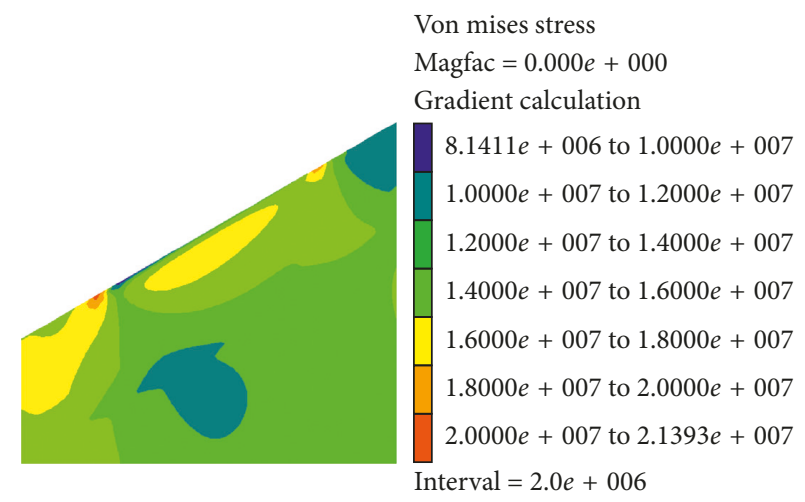

(f)

Figure 3: Equivalent stress of workface floor along the inclined direction of the coal seam with the advancement of the workface. (a) Original equivalent stress. (b) Advanced $20 \mathrm{~m}$ of workface. (c) Advanced $40 \mathrm{~m}$ of workface. (d) Advanced $60 \mathrm{~m}$ of workface. (e) Advanced $80 \mathrm{~m}$ of workface. (f) Advanced $100 \mathrm{~m}$ of workface.

the region with water inrush risk from the inclined coal seam floor.

\subsection{Plastic Failure Zone of Floor along the Inclined Direction of} Coal Seam. Figure 4 shows the plastic failure zone of workface floor along the inclined direction of coal seam. Under the joint effect of mining stress and pore water pressure on the floor strata, plastic failure zones were generated in the workface floor and the top surface of the confined aquifer. The plastic failure zone in the workface floor continuously expanded with the advancement of the workface, as shown in Figure 5. When the workface advanced to about $80 \mathrm{~m}$, the depth of plastic failure zone reached the maximum, and depth was about $15.0 \mathrm{~m}$ at the maximum plastic failure. The depth and range of the plastic failure zone of the workface floor remained unchanged with the continuous advancement of the workface. Moreover, the depth of plastic failure zone in the lower region of the workface floor was the greatest, and the zone was close to the floor aquifer. Therefore, the lower region of the workface floor was the region with water inrush risk from the inclined coal seam floor. 


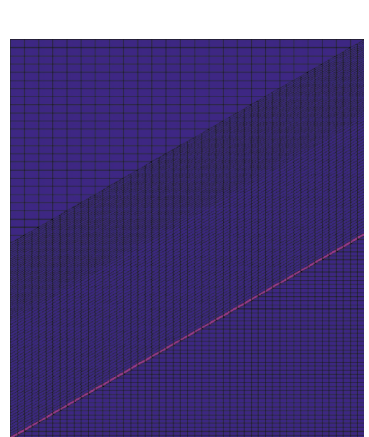

Block state

\section{None}

shear-n shear-p tension- $\mathrm{p}$

shear-n tension- $n$ shear- $p$ tension- $p$

shear-p

shear-p tension- $\mathrm{p}$

tension-n shear-p tension-p

tension-n tension- $\mathrm{p}$

tension-p

(a)

Block state

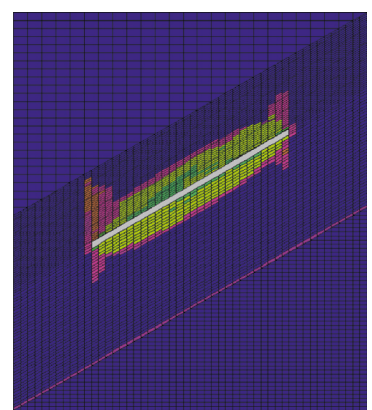

None

shear-n shear-p

shear-n shear-p tension- $\mathrm{p}$

shear-p

shear-p tension-p

tension-n shear-p tension-p

tension-p

(c)

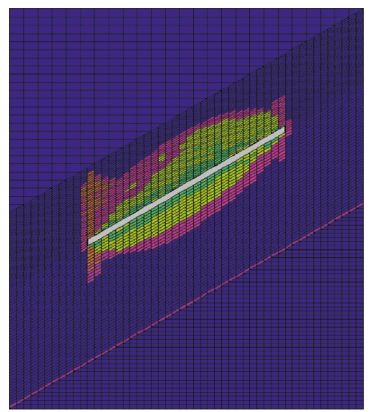

Block state

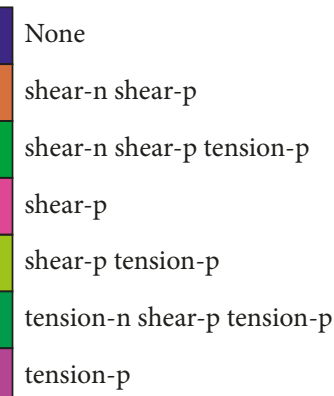

(e)

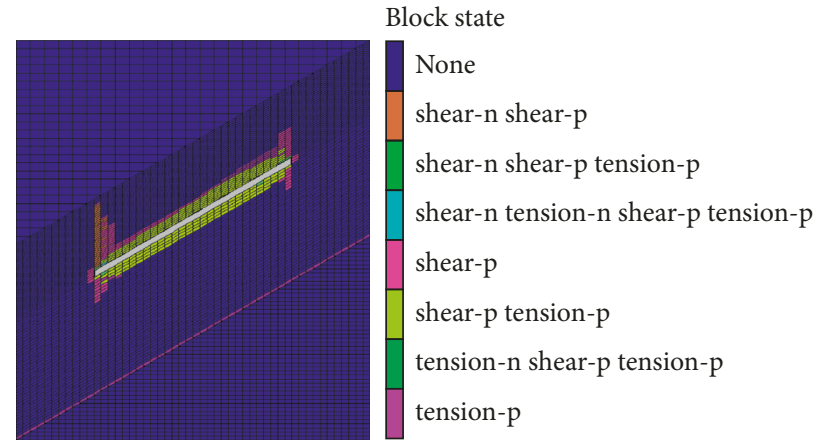

(b)

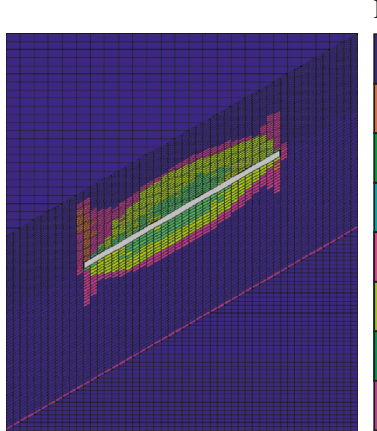

Block state

None

shear-n shear-p

shear-n shear-p tension- $\mathrm{p}$

shear-n tension- $n$ shear-p tension- $\mathrm{p}$

shear-p

shear-p tension-p

tension-n shear-p tension-p

tension-p

(d)

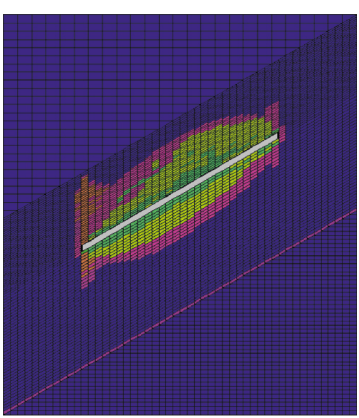

Block state

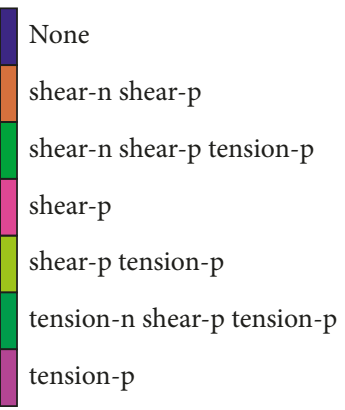

(f)

FIGURE 4: Plastic failure zone of workface floor along the inclined direction of the coal seam with the advancement of the workface. (a) Before workface mining. (b) Advanced $20 \mathrm{~m}$ of workface. (c) Advanced $40 \mathrm{~m}$ of workface. (d) Advanced $60 \mathrm{~m}$ of workface. (e) Advanced $80 \mathrm{~m}$ of workface. (f) Advanced $100 \mathrm{~m}$ of workface.

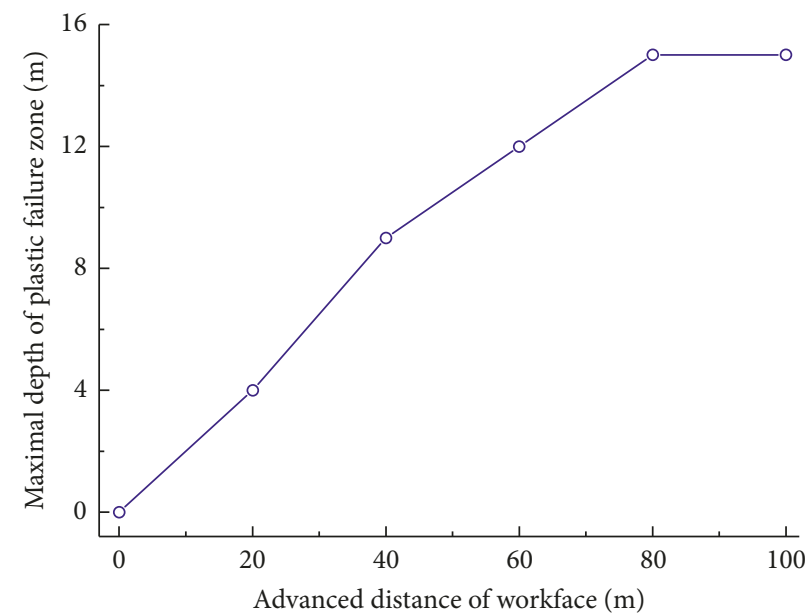

FIGURE 5: Maximal plastic failure depth of workface floor along the inclined direction of coal seam with the advancement of workface. 


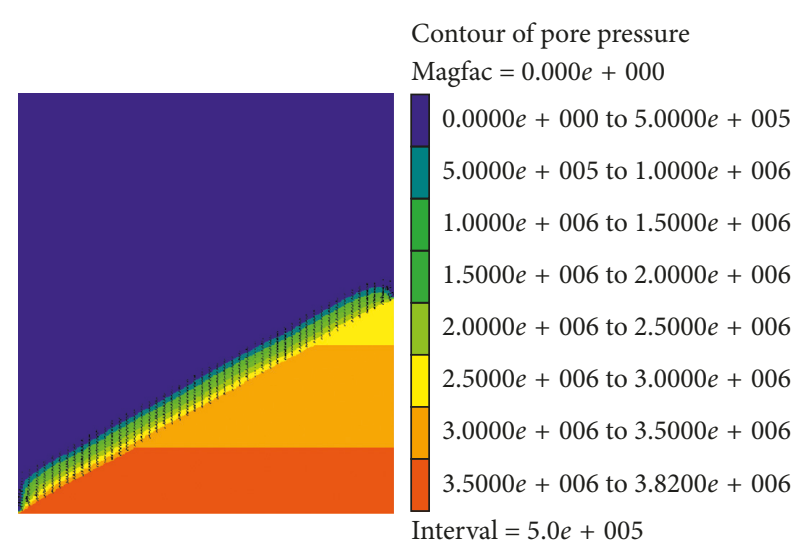

(a)

Contour of pore pressure

Magfac $=0.000 e+000$

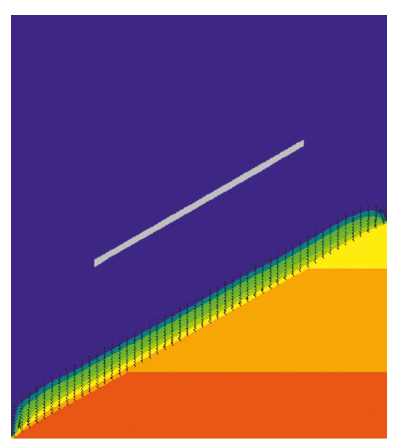

$-\begin{aligned} & 0.0000 e+000 \text { to } 5.0000 e+005 \\ & 5.0000 e+005 \text { to } 1.0000 e+006 \\ & 1.0000 e+006 \text { to } 1.5000 e+006 \\ & 1.5000 e+006 \text { to } 2.0000 e+006 \\ & 2.0000 e+006 \text { to } 2.5000 e+006 \\ & 2.5000 e+006 \text { to } 3.0000 e+006 \\ & 3.0000 e+006 \text { to } 3.5000 e+006 \\ & 3.5000 e+006 \text { to } 3.8200 e+006\end{aligned}$
Interval $=5.0 e+005$

(c)

Contour of pore pressure

Magfac $=0.000 e+000$

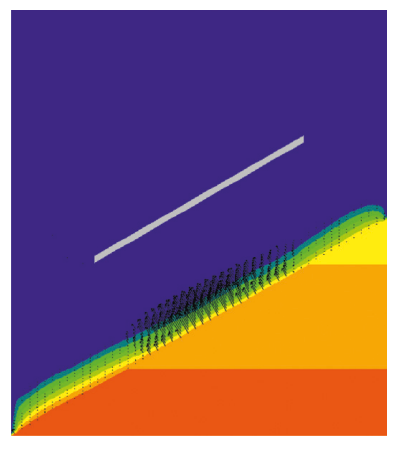

$\begin{aligned} & 0.0000 e+000 \text { to } 5.0000 e+005 \\ & 5.0000 e+005 \text { to } 1.0000 e+006 \\ & 1.0000 e+006 \text { to } 1.5000 e+006 \\ & 1.5000 e+006 \text { to } 2.0000 e+006 \\ & 2.0000 e+006 \text { to } 2.5000 e+006 \\ & 2.5000 e+006 \text { to } 3.0000 e+006 \\ & 3.0000 e+006 \text { to } 3.5000 e+006 \\ & 3.5000 e+006 \text { to } 3.8200 e+006\end{aligned}$
Interval $=5.0 e+005$

(e)
Contour of pore pressure

Magfac $=0.000 e+000$

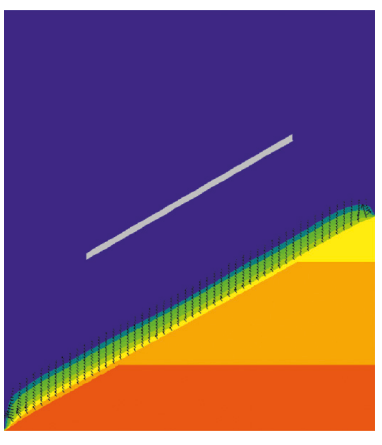

$0.0000 e+000$ to $5.0000 e+005$

$5.0000 e+005$ to $1.0000 e+006$

$1.0000 e+006$ to $1.5000 e+006$

$1.5000 e+006$ to $2.0000 e+006$

$2.0000 e+006$ to $2.5000 e+006$

$2.5000 e+006$ to $3.0000 e+006$

$3.0000 e+006$ to $3.5000 e+006$

$3.5000 e+006$ to $3.8200 e+006$ Interval $=5.0 e+005$

(b)

Contour of pore pressure

Magfac $=0.000 e+000$

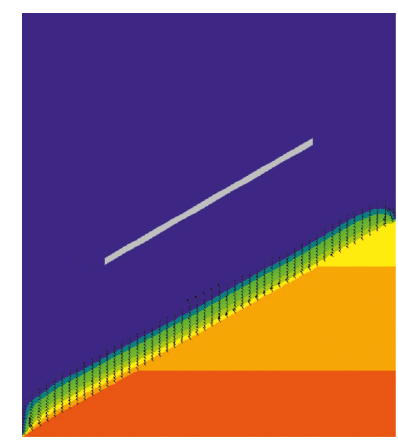

$0.0000 e+000$ to $5.0000 e+005$

$5.0000 e+005$ to $1.0000 e+006$

$1.0000 e+006$ to $1.5000 e+006$

$1.5000 e+006$ to $2.0000 e+006$

$2.0000 e+006$ to $2.5000 e+006$

$2.5000 e+006$ to $3.0000 e+006$

$3.0000 e+006$ to $3.5000 e+006$

$3.5000 e+006$ to $3.8200 e+006$

Interval $=5.0 e+005$

(d)

Contour of pore pressure

Magfac $=0.000 e+000$

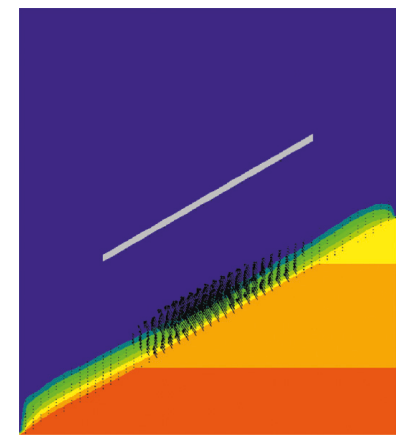

$0.0000 e+000$ to $5.000 e+005$

$5.0000 e+005$ to $1.0000 e+006$

$1.0000 e+006$ to $1.5000 e+006$

$1.5000 e+006$ to $2.0000 e+006$

$2.0000 e+006$ to $2.5000 e+006$

$2.5000 e+006$ to $3.0000 e+006$

$3.0000 e+006$ to $3.5000 e+006$

$3.5000 e+006$ to $3.8200 e+006$

Interval $=5.0 e+005$

(f)

Figure 6: Pore water pressure and seepage vector distribution of workface floor along the inclined direction of the coal seam with the advancement of the workface (no water inrush). (a) Original pore pressure. (b) Advanced $20 \mathrm{~m}$ of workface. (c) Advanced $40 \mathrm{~m}$ of workface. (d) Advanced $60 \mathrm{~m}$ of workface. (e) Advanced $80 \mathrm{~m}$ of workface. (f) Advanced $100 \mathrm{~m}$ of workface.

\section{Confined Permeability Characteristics of an Inclined Coal Seam Floor}

Figure 6 shows the pore water pressure and seepage vector distribution of the workface floor along the inclined direction of the coal seam with the advancement of the workface. Before mining of the workface, the original conducting zone existed at the top surface of the confined aquifer, and the conducting height was about $7 \mathrm{~m}$. The original conducting zone terminated inside the thirteenthlayer siltstone above the aquifer, as shown in number 13 in Table 1. Under the joint effect of mining pressure and aquifer pressure, the confined water-conducting height continuously increased with the continuous advancement of the workface, as shown in Figure 7. The confined waterconducting height reached the maximum value of $11.0 \mathrm{~m}$ when the workface advanced to about $80 \mathrm{~m}$. It terminated inside the eleventh-layer sand mudstone (as shown number 


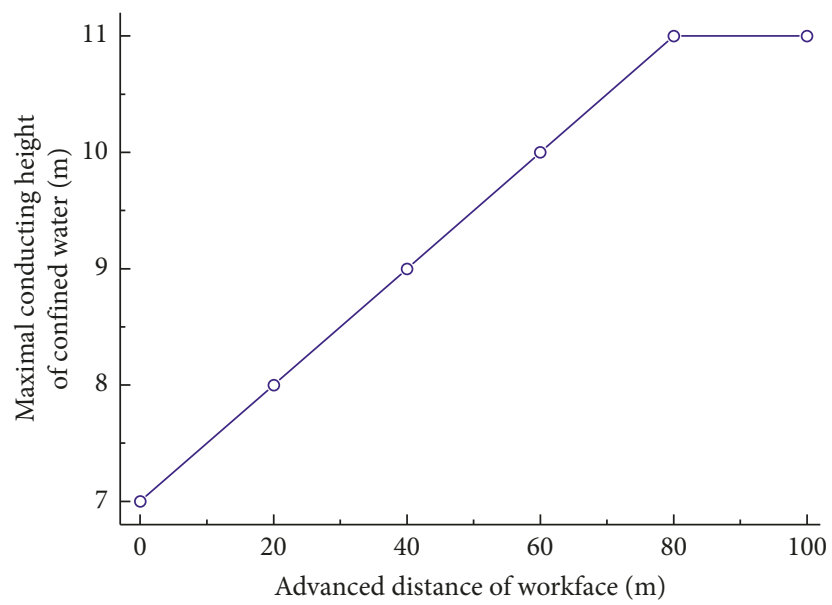

FIGURE 7: Maximal conducting height of confined water of workface floor along the inclined direction of coal seam with the advancement of workface (no water inrush).

TABle 2: Physical and mechanical parameters of the 1066 inclined coal seam workface floor strata after changing.

\begin{tabular}{|c|c|c|c|c|c|c|c|c|c|c|}
\hline Number & Lithology & $\begin{array}{c}\text { Thickness } \\
(\mathrm{m})\end{array}$ & $\begin{array}{c}\text { Density } \\
\left(\mathrm{kg} \cdot \mathrm{m}^{-3}\right)\end{array}$ & $\begin{array}{c}\text { Bulk } \\
\text { modulus } \\
(\mathrm{GPa})\end{array}$ & $\begin{array}{c}\text { Shear } \\
\text { modulus } \\
(\mathrm{GPa})\end{array}$ & $\begin{array}{c}\text { Tensile } \\
\text { strength } \\
(\mathrm{MPa})\end{array}$ & $\begin{array}{c}\text { Cohesion } \\
(\mathrm{MPa})\end{array}$ & $\begin{array}{l}\text { Internal } \\
\text { friction } \\
\text { angle }\left(^{\circ}\right)\end{array}$ & $\begin{array}{c}\text { Permeability } \\
\text { coefficient } \\
\left(\mathrm{m} \cdot \mathrm{s}^{-1}\right)\end{array}$ & Porosity \\
\hline 6 & 10-coal & 3.4 & 1400 & 1.43 & 1.09 & 0.03 & 1.00 & 25 & $1 e-12$ & 0.15 \\
\hline 7 & Siltstone & 6.0 & 2650 & 4.54 & 4.30 & 1.10 & 4.90 & 40 & $7 e-12$ & 0.13 \\
\hline 8 & $\begin{array}{c}\text { Fine } \\
\text { sandstone }\end{array}$ & 9.0 & 2650 & 3.38 & 3.32 & 1.00 & 3.10 & 38 & $5 e-12$ & 0.13 \\
\hline 9 & $\begin{array}{c}\text { Sand } \\
\text { mudstone }\end{array}$ & 6.5 & 2600 & 1.73 & 1.09 & 0.60 & 2.60 & 25 & $0.6 e-11$ & 0.09 \\
\hline 10 & $\begin{array}{l}\text { Medium } \\
\text { sandstone }\end{array}$ & 12.0 & 2650 & 2.78 & 2.63 & 0.75 & 3.50 & 41 & $0.8 e-11$ & 0.12 \\
\hline 11 & $\begin{array}{l}\text { Sand } \\
\text { mudstone }\end{array}$ & 9.0 & 2600 & 1.73 & 1.09 & 0.45 & 2.90 & 25 & $0.6 e-13$ & 0.09 \\
\hline 12 & $\begin{array}{l}\text { Medium } \\
\text { sandstone }\end{array}$ & 3.0 & 2650 & 2.78 & 2.63 & 0.75 & 3.50 & 41 & $0.8 e-11$ & 0.12 \\
\hline 13 & Siltstone & 5.5 & 2650 & 4.54 & 4.30 & 1.00 & 4.40 & 40 & $0.5 e-11$ & 0.14 \\
\hline 14 & $\begin{array}{l}\text { Medium } \\
\text { sandstone }\end{array}$ & 2.0 & 2650 & 2.78 & 2.63 & 0.75 & 3.50 & 41 & $0.8 e-11$ & 0.12 \\
\hline 15 & Aquifer & 90.0 & 2500 & 4.20 & 3.12 & 1.40 & 3.20 & 38 & $1 e-10$ & 0.31 \\
\hline
\end{tabular}

11 in Table 1) above the aquifer and then remained unchanged with the advancement of the workface.

Pressure relief range of the floor also continuously expanded with the continuous advancement of the workface, which resulted in the continuous change of pore water pressure and seepage velocity in the workface floor strata. When the workface advanced to about $60 \mathrm{~m}$, pore water pressure and seepage velocity in the workface floor strata changed. When the workface advanced to about $80 \mathrm{~m}$, pore water pressure and seepage velocity in the workface floor strata clearly changed and then remained unchanged with the continuous advancement of the workface.

The floor mining failure depth and confined waterconducting height continuously increased with the advancement of the workface and reached the maximum value when the workface advanced to about $80 \mathrm{~m}$.
However, the barrier effect of the "soft-hard-soft" compound water-resistant strata composed by sand mudstone, medium sandstone, and sand mudstone of the workface floor, as shown numbers 9, 10, and 11 in Table 1, which existed between the floor mining failure zone and the confined water-conducting zone in the 1066 workface floor, could buffer the floor mining failure depth, obstruct the further progressive conducting of the confined water, and inhibit the occurrence of water inrush from the workface floor [18-20]. Therefore, when the workface advanced to about $80 \mathrm{~m}$, if the confined water did not break through the "soft-hard-soft" compound waterresistant strata in the 1066 inclined workface floor, then the compound water-resistant strata would always maintain a favorable water-resisting performance, and it could effectively obstruct water inrush from the inclined coal seam floor $[21,22]$. 


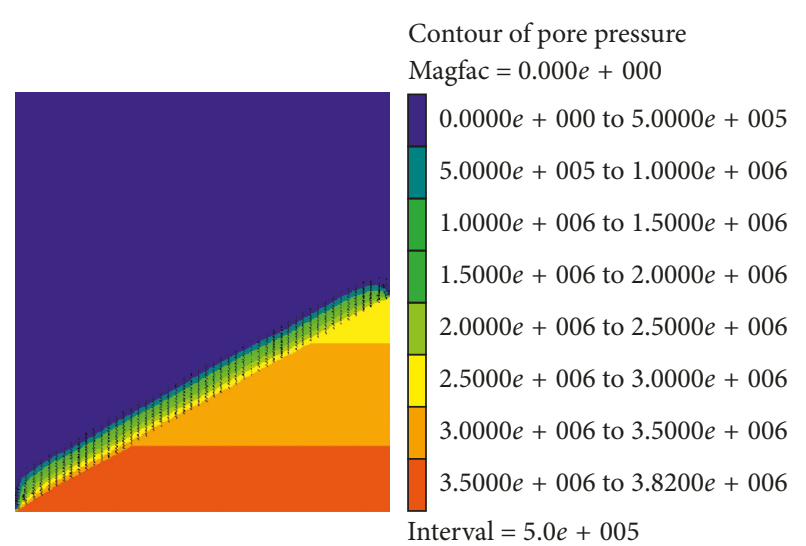

(a)

Contour of pore pressure

Magfac $=0.000 e+000$

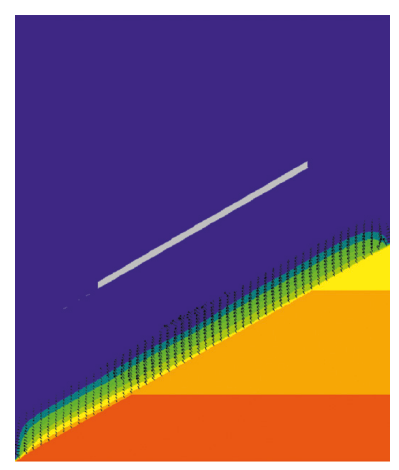

$0.0000 e+000$ to $5.0000 e+005$
$5.0000 e+005$ to $1.0000 e+006$
$1.0000 e+006$ to $1.5000 e+006$
$1.5000 e+006$ to $2.0000 e+006$
$2.0000 e+006$ to $2.5000 e+006$
$2.5000 e+006$ to $3.0000 e+006$
$3.0000 e+006$ to $3.5000 e+006$
$3.5000 e+006$ to $3.8200 e+006$
Interval $=5.0 e+005$

(c)

Contour of pore pressure

Magfac $=0.000 e+000$

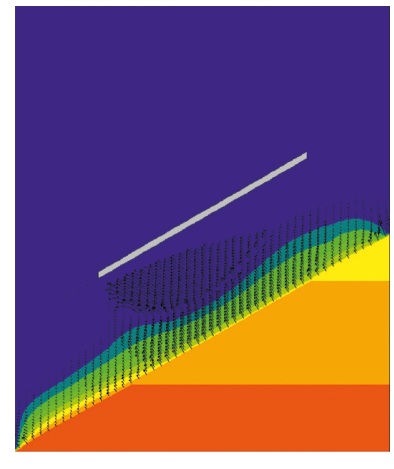

$0.0000 e+000$ to $5.0000 e+005$
$5.0000 e+005$ to $1.0000 e+006$
$1.0000 e+006$ to $1.5000 e+006$
$1.5000 e+006$ to $2.0000 e+006$
$2.0000 e+006$ to $2.5000 e+006$
$2.5000 e+006$ to $3.0000 e+006$
$3.0000 e+006$ to $3.5000 e+006$
$3.5000 e+006$ to $3.8200 e+006$
Interval $=5.0 e+005$

(e)
Contour of pore pressure

Magfac $=0.000 e+000$

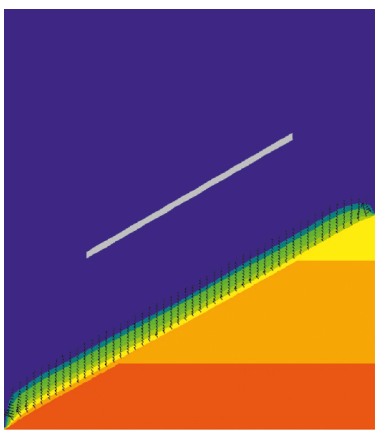

$0.0000 e+000$ to $5.0000 e+005$

$5.0000 e+005$ to $1.0000 e+006$

$1.0000 e+006$ to $1.5000 e+006$

$1.5000 e+006$ to $2.0000 e+006$

$2.0000 e+006$ to $2.5000 e+006$

$2.5000 e+006$ to $3.0000 e+006$

$3.0000 e+006$ to $3.5000 e+006$

$3.5000 e+006$ to $3.8200 e+006$

Interval $=5.0 e+005$

(b)

Contour of pore pressure

Magfac $=0.000 e+000$

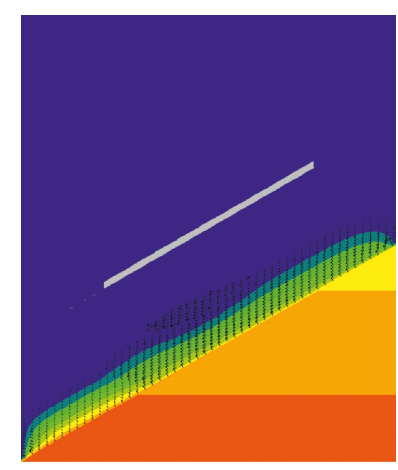

$0.0000 e+000$ to $5.0000 e+005$

$5.0000 e+005$ to $1.0000 e+006$

$1.0000 e+006$ to $1.5000 e+006$

$1.5000 e+006$ to $2.0000 e+006$

$2.0000 e+006$ to $2.5000 e+006$

$2.5000 e+006$ to $3.0000 e+006$

$3.0000 e+006$ to $3.5000 e+006$

$3.5000 e+006$ to $3.8200 e+006$

Interval $=5.0 e+005$

(d)

Contour of pore pressure

Magfac $=0.000 e+000$

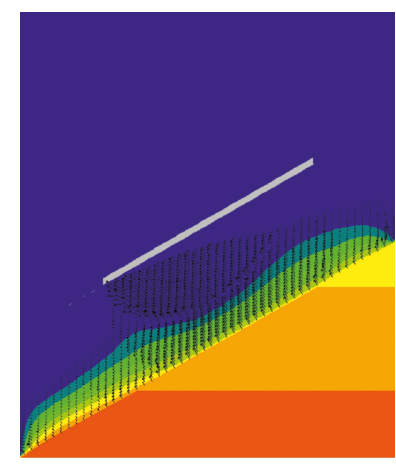

$0.0000 e+000$ to $5.0000 e+005$

$5.0000 e+005$ to $1.0000 e+006$

$1.0000 e+006$ to $1.5000 e+006$

$1.5000 e+006$ to $2.0000 e+006$

$2.0000 e+006$ to $2.5000 e+006$

$2.5000 e+006$ to $3.0000 e+006$

$3.0000 e+006$ to $3.5000 e+006$

$3.5000 e+006$ to $3.8200 e+006$

Interval $=5.0 e+005$

(f)

Figure 8: Pore water pressure and seepage vector distribution of workface floor along the inclined direction of the coal seam with the advancement of the workface (water inrush). (a) Original pore pressure. (b) Advanced $20 \mathrm{~m}$ of workface. (c) Advanced $40 \mathrm{~m}$ of workface. (d) Advanced $60 \mathrm{~m}$ of workface. (e) Advanced $80 \mathrm{~m}$ of workface. (f) Advanced $100 \mathrm{~m}$ of workface.

\section{Position of an Inclined Coal Seam Floor with Easy Water Inrush}

To determine the position of the 1066 inclined coal seam workface floor with easy water inrush, the physical and mechanical parameters of the 1066 inclined coal seam workface floor strata were changed, especially the strata parameters of the "soft-hard-soft" compound waterresistant strata (composed by sand mudstone, medium sandstone, and sand mudstone) of the workface floor between floor mining failure zone and confined waterconducting zone. Moreover, the intensity of the floor strata was reduced, and the permeability was strengthened. Table 2 shows the physical and mechanical parameters of the 


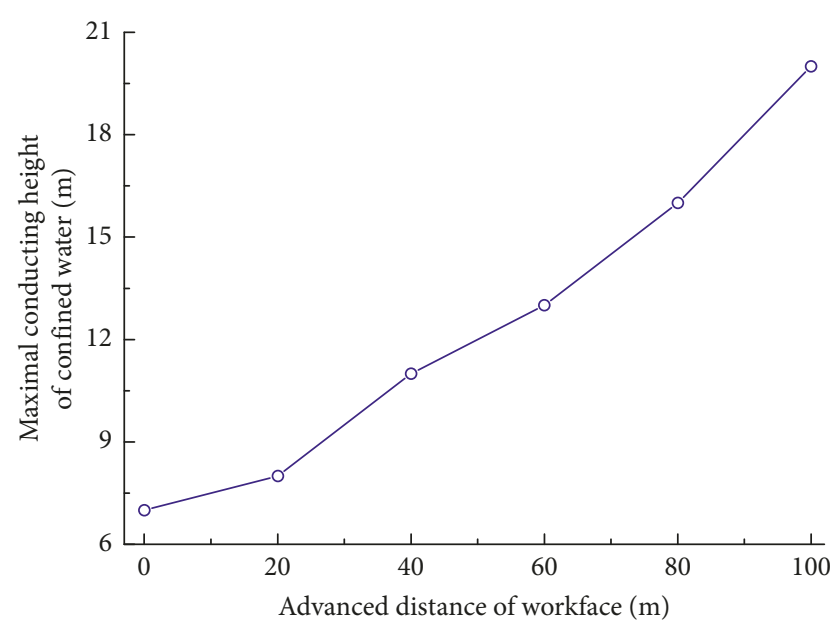

Figure 9: Maximal conducting height of confined water of workface floor along the inclined direction of coal seam with the advancement of workface (water inrush).

1066 inclined coal seam workface floor strata obtained by the same method as above after changing from number 6 to number 15 .

Figure 8 shows the pore water pressure and seepage vector distribution of workface floor along the inclined direction of the coal seam with the advancement of the workface after the strata parameters of the 1066 workface floor were changed. As shown in Figure 8, the original conducting zone existed at the top surface of the confined aquifer before workface mining, and the conducting height was about $7 \mathrm{~m}$, which was equivalent to the original confined water-conducting zone before the strata parameters of the 1066 workface floor were changed. Under the joint effect of mining pressure and aquifer pressure, the confined waterconducting height continuously increased with the continuous advancement of the workface, as shown in Figure 9. When the workface advanced to about $80 \mathrm{~m}$, the confined water-conducting height reached about $16.0 \mathrm{~m}$, which increased by $5.0 \mathrm{~m}$ compared with that before the strata parameters of the 1066 workface floor were changed.

Pressure relief range of the inclined workface floor also continuously expanded with the advancement of the workface, which gave rise to the continuous change of pore water pressure and seepage velocity in the workface floor strata. The change was faster and more apparent compared with that before the strata parameters of the workface floor were changed. When the workface advanced to about $40 \mathrm{~m}$, pore water pressure and seepage velocity in the workface floor strata clearly changed. When the workface advanced to about $60 \mathrm{~m}$, seepage velocity at the lower side of the workface floor strata was clearly higher than those in other positions, indicating that the fracture which developed at the lower side of the workface floor strata was higher and had strong permeability. When the workface continuously advanced to about $80 \mathrm{~m}$, seepage velocity at the lower side of the workface floor strata further increased, and the confined pore water pressure broke through the "soft-hard-soft" compound water-resistant strata of the 1066 inclined workface floor, as shown numbers 9,10 , and 11 in Table 2 . As a result, the confined water-conducting zone and floor mining failure broke through and water inrush might occur at the lower region of the workface floor. When the workface continuously advanced to about $100 \mathrm{~m}$, the confined waterconducting zone and floor mining failure broke through, and water inrush occurred at the lower region of the workface floor. Therefore, the lower region of the workface floor is the position with the highest water inrush risk for inclined workface floor strata without a structural defect.

\section{Conclusion}

Secondary development of FLAC ${ }^{3 \mathrm{D}}$ software was carried out based on FISH language, and a 3D fluid-solid coupling numerical simulation model for inclined coal seam mining above a confined aquifer in Taoyuan Coal Mine was established. A simulation study was implemented on mining failure depth of the inclined coal seam floor, conducting height of the confined water, and position of the workface floor with easy water inrush during advancement of the workface. The main conclusions obtained are as follows:

(1) Pressure relief range of floor strata continuously expanded with the advancement of the inclined workface, and it remained unchanged until the workface advanced to over $80 \mathrm{~m}$. Obvious, equivalent stress concentration zones existed in floor strata during the advancement process of the workface. The concentration degree reached the maximum when the workface advanced to about $80 \mathrm{~m}$, and the largest equivalent stress concentration zone was located at the lower side of the workface floor, so that the water inrush danger at the lower region of the workface floor was greater.

(2) Plastic failure zone of the workface floor continuously expanded with the advancement of the inclined workface. The depth of plastic failure zone reached the maximum value of $15.0 \mathrm{~m}$ when the workface advanced to $80 \mathrm{~m}$. The maximum plastic failure depth was at the lower region of the workface floor, which was close to the aquifer. Therefore, water inrush danger was greater at the lower region of the workface floor.

(3) Original confined water conducting existed at the upper part of the confined aquifer before mining of the inclined coal seam workface, and the conducting height was about $7 \mathrm{~m}$. The confined waterconducting height continuously increased with the advancement of the workface and reached the maximum conducting height of $11.0 \mathrm{~m}$ when the workface advanced to about $80 \mathrm{~m}$.

(4) Pore water pressure and seepage velocity at the workface floor strata continuously changed with the advancement of the inclined workface. However, pore water pressure and seepage velocity remained unchanged after the workface advanced to over $80 \mathrm{~m}$ owing to the barrier effect of "soft-hard-soft" 
compound water-resistant strata of the workface floor. After the strata parameters of the workface floor were changed, the confined pore water pressure could pass the lower region of the workface floor strata and rush into the mining workface after breaking the obstruction of the "soft-hard-soft" compound water-resistant strata of the workface floor, which gave rise to water inrush from the inclined coal seam floor.

\section{Data Availability}

The data used to support the findings of this study are available from the corresponding author upon request.

\section{Conflicts of Interest}

The authors declare that there are no conflicts of interest regarding the publication of this paper.

\section{Acknowledgments}

This study was supported by the National Natural Science Foundation of China (no. 51404013), the Open Projects of State Key Laboratory of Coal Resources and Safe Mining (no. 13KF01), and the Major Research Funding Project of Natural Science of Anhui Province University (no. KJ2018ZD010). In addition, the corresponding author would like to express his sincere thanks and appreciation to Assistant Professor Ting Ren for providing the visit opportunities in the University of Wollongong.

\section{References}

[1] M. Xiexing, L. Weiqun, and C. Zhanqing, Seepage Theory of Mining Rockmass, Science Press, Beijing, China, 2004.

[2] W. Jin'an, W. Xianhao, and C. Shaojie, "Fracture and seepage characteristics in the floor strata when mining above a confined aquifer," Journal of China University of Mining and Technology, vol. 41, no. 4, pp. 536-542, 2012.

[3] Z. Jincai, Z. Yuzhuo, and L. Tianquan, Rock Mass Permeability and Coal Mine Water Inrush, Geological Publishing House, Beijing, China, 1997.

[4] L. Zhijun and H. Yaoqing, "Solid-liquid coupling study on water inrush through faults in coal mining above confined aquifer," Journal of China Coal Society, vol. 32, no. 10, pp. 1046-1050, 2007.

[5] Y. Tianhong, T. Chun'an, T. Zhihong, Z. Wancheng, and F. Qiyan, "State of the art of inrush models in rock mass failure and developing trend for prediction and forecast of groundwater inrush," Chinese Journal of Rock Mechanics and Engineering, vol. 26, no. 2, pp. 268-277, 2007.

[6] Y. Shangxian and H. Weiyue, "Rocks' water-resistance ability and natural progressive intrusion height," Coal Geology and Exploration, vol. 36, no. 1, pp. 34-36, 2008.

[7] H. Fenghua and J. Yuanjiang, "Fluid-solid coupling analysis of water inrush in mine floor of soft and hard interbedded rocks," Safety in Coal Mines, vol. 42, no. 6, pp. 15-18, 2011.

[8] Y. Duoxi and L. Haifeng, "Seepage field-strain field coupling analysis for rock masses of coal seam floor during mining above confined aquifer," Chinese Journal of Rock Mechanics and Engineering, vol. 31, pp. 2738-2744, 2012.
[9] H. Wei and X. Dejin, "Application of finite element strength reduction method to risk assessment of groundwater inrush from coal seam floor," Journal of China Coal Society, vol. 38, no. 1, pp. 27-32, 2013.

[10] L. Wenmin, G. Zhaoning, M. Xiangrui, Z. Fengda, L. Qi, and Y. Lin, "The fluid-solid coupling numerical simulation of mining above confined water," Safety in Coal Mines, vol. 44, no. 2, pp. 57-60, 2013.

[11] Z. Xiaorong, Z. Hongmei, D. Zhongsi, W. Jiwen, S. Shuhao, and Z. Shengquan, "Study on fluid-solid coupling mechanism for water resistance effect of coal floor based on different combination of rock strata," Journal of Safety Science and Technology, vol. 12, no. 7, pp. 16-21, 2016.

[12] Z. Yanlin, C. Ping, W. Wen, W. Weijun, Z. Shengguo, and Z. Shenghua, "Fluid-solid coupling analysis of water bursting catastrophe from concealed confined karst cave before roadway," Journal of Central South University, vol. 45, no. 5, pp. 1598-1604, 2014.

[13] S. Jian, Failure Characteristics and Water-Inrush Mechanism of an Inclined Coal Seam Floor, University of Mining and Technology, Xuzhou, China, 2011.

[14] S. Jian, "Failure characteristics of floor "three-zone" along the inclined direction of coal seam," Journal of Mining and Safety Engineering, vol. 31, no. 1, pp. 115-121, 2014.

[15] S. Jian and W. Lianguo, "Instability mechanics criterion of inclined water-resisting key strata in coal seam floor," Journal of China Coal Society, vol. 39, no. 11, pp. 2276-2285, 2014.

[16] S. Jian, W. Lianguo, T. Furong, S. Yifeng, and G. Shilong, "Microseismic monitoring on the failure characteristics of an inclined coal seam floor," Rock and Solid Mechanics, vol. 32, no. 5, pp. 1589-1595, 2011.

[17] D. Elsworth and B. Mao, "Flow-deformation response of dualporosity media," Journal of Geotechnical Engineering, vol. 118, no. 1, pp. 107-124, 1992.

[18] M. Xiexing, C. Ronghua, and B. Haibo, "Fundamental concepts and mechanical analysis of water-resisting key strata in water-preserved mining," Journal of China Coal Society, vol. 32, no. 6, pp. 561-564, 2007.

[19] M. Xiexing, P. Hai, and B. Haibo, "Principle of water-resisting key strata and its application in water-preserved mining," Journal of China University of Mining and Technology, vol. 37, no. 1, pp. 1-4, 2008.

[20] S. Jian, W. Lianguo, and H. Huaqiang, "Resurch on waterisolating capacity of the compound water-resisting key strata in coal seam floor," Journal of China University of Mining and Technology, vol. 42, no. 4, pp. 560-566, 2013.

[21] S. Jian, H. Yang, and Z. Guangming, "Relationship between water inrush from coal seam floors and main roof weighting," International Journal of Mining Science and Technology, vol. 27, no. 5, pp. 873-881, 2017.

[22] C. Yang, L. Shengdong, and L. Lu, "Water abundance of mine floor limestone by simulation experiment," International Journal of Mining Science and Technology, vol. 26, no. 3, pp. 495-500, 2016. 


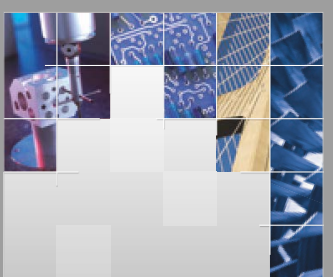

\section{Enfincering}
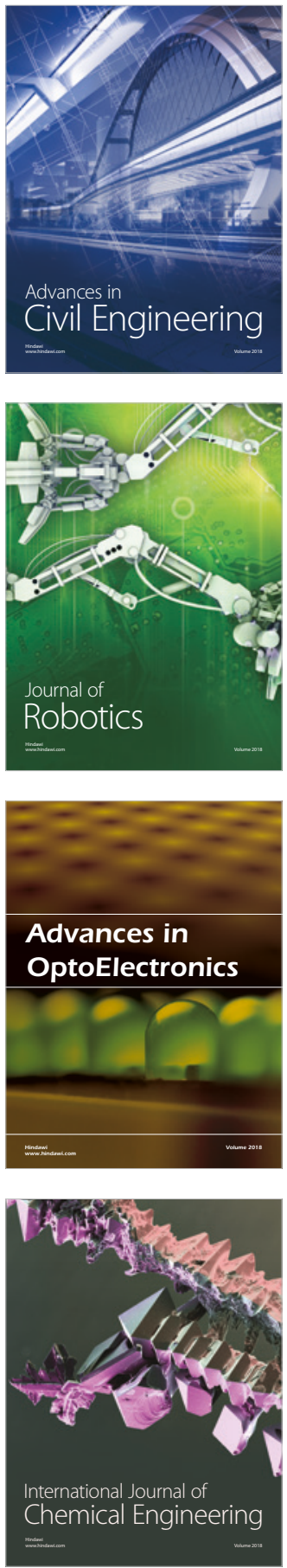

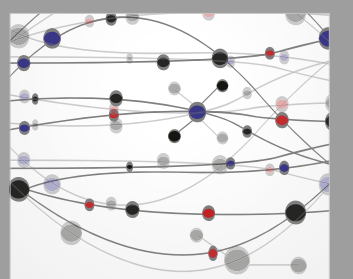

\section{Rotating \\ Machinery}

The Scientific World Journal

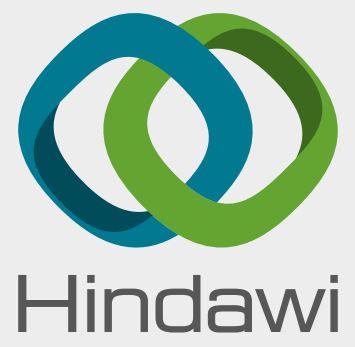

Submit your manuscripts at

www.hindawi.com
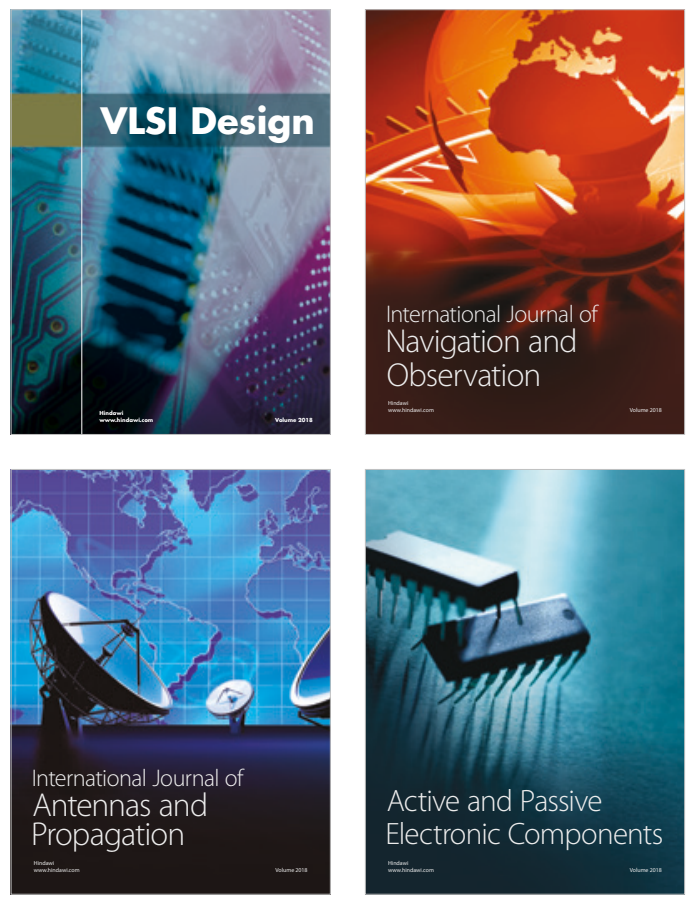
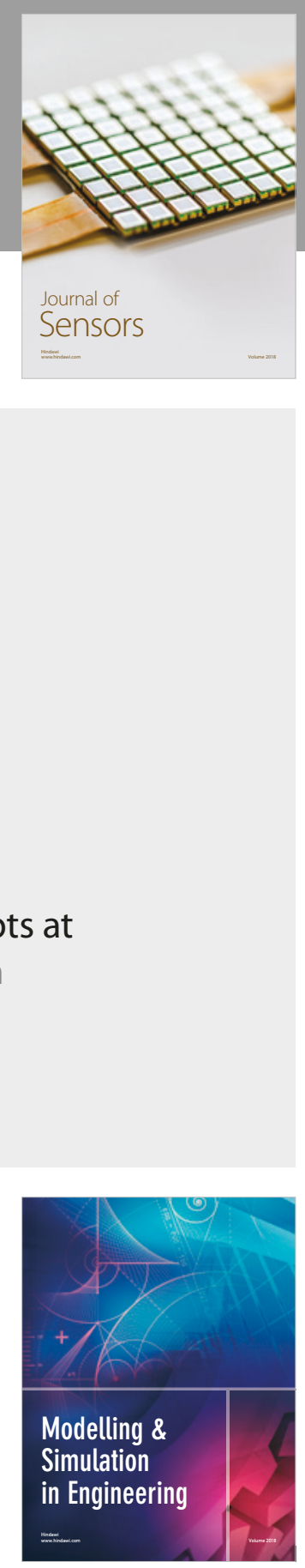

\section{Advances \\ Multimedia}
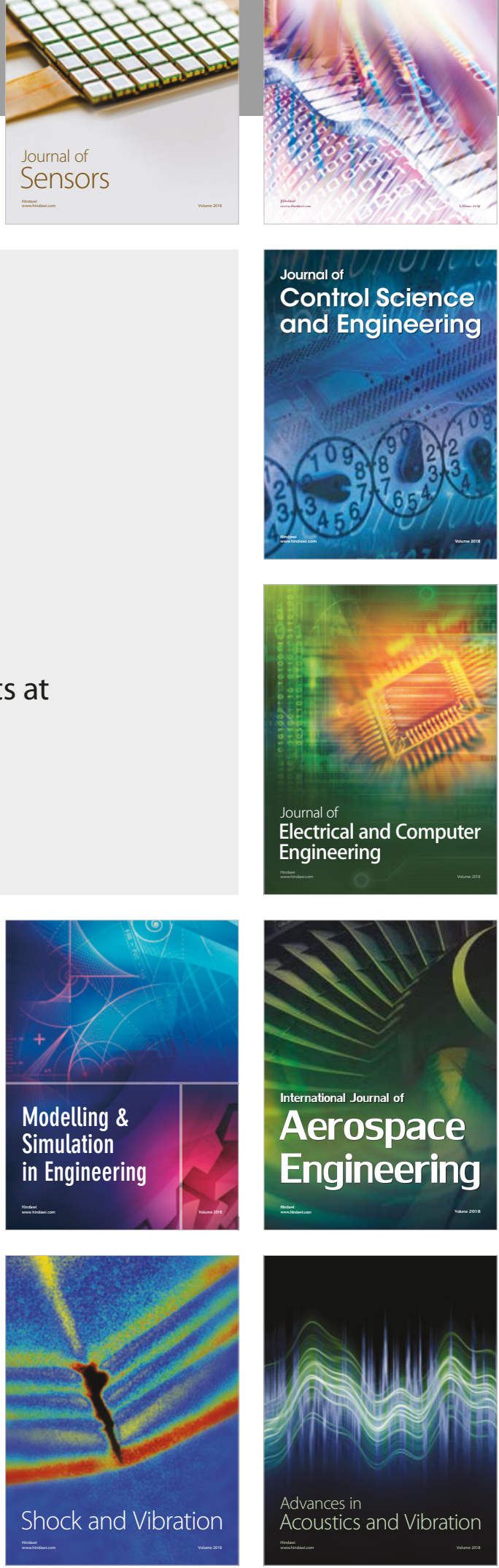